СД-15.

\title{
ПОДБОР ОПТИМАЛЬНОГО СПОСОБА ПРОБОПОДГОТОВКИ ГОРНЫХ ПОРОД БАЖЕНОВСКОЙ СВИТЫ И РАЗРАБОТКА МЕТОДИЧЕСКИХ РЕКОМЕНДАЦИЙ, УЧИТЫВАЮЩИХ МАТРИЦУ ДЛЯ ОПРЕДЕЛЕНИЯ МИКРОКОМПОНЕНТОВ МЕТОДОМ АЭС-ИСП.
}

Капустянская П. А., Вторушина Э. А., Куклина В. М.

АУ «Научно-аналитический центр рационального недропользования им. В.И. Шпильмана», Ханты-Мансийск, Россия

kapustyanskayaPA@nacrn.hmao.ru

DOI: 10.26902/ASFE-11_108

В настоящее время остро стоит вопрос изучения макро и микроэлементного состава горных пород, в частности - пород Баженовской свиты (БС), являющейся одним из наиболее исследуемых, но при этом наименее изученным объектов. Знание элементного состава и установленная закономерность распределения этих элементов способствует построению моделей геологических процессов $[1,2]$.

БС представлена тонкослоистыми карбонатно-глинисто-кремнистыми отложениями, обогащенными органическим веществом. Битуминозность отложений, неоднородность вещественного состава как по вертикали, так и по горизонтали, высокое содержание в них пирита обуславливают поиск новых подходов к пробоподготовке и анализу. Принимая во внимание данные особенности, необходимо в качестве калибровочных стандартов использовать растворы, учитывающие сложную матрицу объекта, а также подобрать оптимальные условия пробоподготовки.

Данная работа посвящена поиску наиболее эффективных способов разрушения сложной органоминеральной матрицы горных пород, позволяющих достичь максимальной степени извлечения микроэлементов, а также разработке методических подходов их определения методом атомно-эмиссионной спектрометрии с индуктивно-связанной плазмой (АЭС-ИСП).

В ходе работы были выбраны оптимальные условия деструкции сложной матрицы и извлечения из нее элементов, находящихся в породе в следовых количествах, методами кислотного выщелачивания и сплавления. Учет сложной химической структуры осуществлен путем использования в качестве градуировочных стандартов ГСО различного состава, таких как СГХМ-4, СИ-2, СГД-2А, СГ-3 и др., предварительно переведенных в растворенную форму. Проведена оценка точности, повторяемости и воспроизводимости результатов.

\section{Список литературы}

1. Бобров В. А. Микроэлементы как индикаторы геологических процессов. Сб. науч. тр. - 1982.

2. Аношин Г. Н., Заякина С. Б. Химический анализ в геологии и геохимии //ред. Аношин ГН Новосибирск:

Академическое изд-во «Гео». - 2016. - С. 235-243. 